\title{
IDENTIFIKASI DAN EVALUASI AKSES PUBLIK DAN OPEN SPACE DI KAWASAN SENG HIE PONTIANAK
}

\author{
Bontor Jumaylinda Br. Gultom \\ Program Studi Arsitektur \\ Universitas Tanjungpura, Pontianak \\ bontor_jl@teknik.untan.ac.id
}

\section{Yudi Purnomo}

Program Studi Arsitektur

Universitas Tanjungpura, Pontianak

\author{
Ivan Gunawan \\ Program Studi Arsitektur \\ Universitas Tanjungpura, Pontianak
}

\begin{abstract}
Abstrak
Sungai merupakan milik publik, sungai tidak hanya bisa dimanfatkan untuk media transportasi, tapi juga merupakan kekayaan alam yang dapat dinikmati secara visual. Jika dapat dinikmati dengan leluasa, masyarakat juga dapat mengawasi pemanfaatan sungai. Sungai yang tidak dapat diawasi dapat mengakibatkan kerusakan dan pencemaran sungai. Kota Pontianak merupakan kota air (waterfront city) yang pengembangannya mengharuskan menghargai sungai sebagai pusat orientasi. Sebagai media yang membantu berjalannya aktifitas transportasi dan pelayanan kegiatan perdagangan, sungai Kapuas merupakan milik publik. Untuk itu sungai harus bisa diakses publik dan dapat dinikmati sebagai area pelayanan masyarakat. Masyarakat berhak mengakses ke arah sungai, menikmati pemandangan dan aktifitas sungai, sehingga dapat ikut menjaga fasilitas yang disediakan bagi kepentingan publik. Namun dewasa ini, aktifitas di tepian sungai Kapuas di wilayah Seng Hie terbatas hanya pada pengguna langsung dari kawasan waterfront tersebut, yaitu pengguna sampan dan yang sudah terbiasa melakukan aktifitas memancing. Kondisi tersebut menjadi latar belakang penelitian, yang bertujuan untuk menganalisis keberadaaan akses publik dan open space di kawasan waterfront Seng Hie, serta apakah akses publik dan open space yang tersedia sudah memudahkan masyarakat untuk berhubungan langsung dan menikmati area waterfront, sehingga sesuaian dengan kaidah waterfront. Penelitian dilakukan dalam 2 (dua) tahap, yaitu mengidentifikasi akses publik dan open space di kawasan waterfront Seng Hie dan evaluasi kesesuaian dengan kaidah waterfront.

Kawasan waterfront Seng Hie, memiliki keunikan yang memberi karakter yang menjadi citra Kota Pontianak. Anmun, berikut adalah hasil temuan dalam penelitian ini. Akses publik dan open space belum mampu menarik perhatian pengunjung. Akses yang berhadapan dengan jalan kebanyakan ditutupi dengan adanya PKL yang kumuh dan membuat orang tidak tertarik untuk berkunjung. Akses yang tersedia beragam lebar dan kondisi fisiknya, ada yang permanen namun ada juga yang masih menggunakan kayu dengan konstruksi yang rusak dan sudah tua. Kawasan ini telah dilengkapi dengan adanya promenade namun belum bisa melayani aktifitas publik dan memberi kenyamanan pada pengunjung. Terdapat aktifitas unik yaitu penyeberangan sungai menggunakan sampan. Tapi, belum terdapat sarana untuk bersosialisasi dengan maksimal. Promenade belum memberikan rasa nyaman dan aman, karena belum tersedia pagar pembatas agar pengunjung tidak jatuh ke sungai.
\end{abstract}


Kata Kunci: Seng Hie, waterfront, akses publik, ruang terbuka

\begin{abstract}
River is a public property. The river is can not only be used for the transportion, but also as a natural resource that can be enjoyed visually. If it can be enjoyed freely, people can also controll the use of the river. A river that can not be monitored can make the river damage and create a pollution. Pontianak is a riverfront city which it development requires a river as the center of the development orientation. As the transport medium and service trade, the Kapuas river should be accessible to the public and can be enjoyed as a public area. The public have a right to access the river, enjoy the scenery and river activities, and uses the facilities provided. In fact, the activity on the banks of the Kapuas river in the Seng Hie area, strictly limited to the direct users of the waterfront area. Communities outside the region can not enjoy waterfront area freely.

This study aimed to analyze the existence of public access and open space in the Seng Hie area, whether it meets the requirements according to the rules of designing waterfront region. Stages of analysis used in the study consists of two phases, which is identifies public access and open space in the Seng Hie region and evaluate the suitability of the first stage identification result to the rules of designing waterfront region.

Seng Hie area has a unique character that gives the image of the city of Pontianak. This area has the potential to be developed. This area already has the appeal of the inherent function, namely trade. This makes this area very easily become a magnet to invite more people to visit.
\end{abstract}

Keywords: Seng Hie, waterfront, public access, open space

\title{
1. Pendahuluan
}

Secara geografis, Kota Pontianak berada di tepian Sungai Kapuas dan Sungai Melawi, kondisi ini menurut Garnham (1985) menjadikan kota Pontianak memiliki potensi alam yang dapat dikembangkan menjadi citra pembentuk kota. Hal ini diperkuat dengan sejarah Kota Pontianak yang menitikberatkan sungai sebagai media utama dalam membantu jalannya semua kegiatan penduduk Kota Pontianak, seperti mandi, sumber air minum, kegiatan jualbeli, serta kegiatan transportasi sungai menggunakan sampan atau kapal. Bahkan pada saat pendiriannya, pusat Kota Pontianak berupa kesultanan Kadariah Pontianak berada di tepian sungai Kapuas, tepatnya berada di kawasan Beting. Bukti ini mengindikasikan bahwa Kota Pontianak seharusnya memiliki dan pengembangkan citra kota berdasarkan pada potensi air, atau menggunakan kaidah kota air atau lebih dikenal dengan waterfront city.

Sungai sebagai warisan kekayaan alam, memang sungai tidak harus menjadi satusatunya media yang dapat membantu berjalannya aktifitas penduduk sekitar waterfront city. Tetapi, dengan adanya media alternatif yang difokuskan pada daerah darat, sungai tidak seharusnya ditinggalkan, mengingat potensi sungai yang sangat besar maka sungai tetap harus diperhatikan.

Kondisi eksisting yang terjadi di kota Pontianak, perkembangan kota lebih menitiberatkan pada bagian darat (Maryono dan Parikesit, 2003), sungai yang sebelumnya sebagai media transportasi, menjadi tertinggal. Yang tertinggal adalah kawasan yang terletak di kawasan waterfront dan masih memiliki fungsi permukiman, perdagangan, serta kawasan pelabuhan, atau bahkan hanya titik-titik pelayanan transportasi sampan yang masih digunakan penduduk sekitar sungai. Konsentrasi kegiatan kota tidak lagi terjadi di sungai. Sungai hanya dilewati jika penduduk berpindah dari bagian sisi sungai yang satu ke sisi sungai yang lain atau sebaliknya, dan itupun dilakukan menggunakan jembatan. Penduduk 
kota yang tidak tinggal di tepian sungai, hanya bisa menikmati sungai hanya dari beberapa titik yang ditetapkan berupa ruang terbuka, yaitu di sekitar alun-alun Kota Pontianak.

Sungai merupakan milik publik, sungai tidak hanya bisa dimanfatkan untuk media transportasi, tapi juga merupakan kekayaan alam yang dapat dinikmati secara visual. Jika dapat dinikmati dengan leluasa, masyarakat juga dapat mengawasi pemanfaatan sungai. Sungai yang tidak dapat diawasi dapat mengakibatkan kerusakan dan pencemaran sungai. Namun bagaimana sungai dapat dinikmati dan diawasi, cara yang tepat dan sesuai menurut Department of City Planning Waterfront Urban Design Technical Advisory Committee (1997), yaitu dengan mengikuti kaidah waterfront city, dengan membuat akses publik dan open space di kawasan waterfront kota Pontianak.

Kota Pontianak merupakan kota air (waterfront city) yang pengembangannya mengharuskan menghargai sungai sebagai pusat orientasi. Sebagai media yang membantu berjalannya aktifitas transportasi dan pelayanan kegiatan perdagangan, sungai Kapuas sebenarnya adalah milik publik. Untuk itu sungai harus bisa diakses publik dan dapat dinikmati sebagai area pelayanan masyarakat. Masyarakat berhak mengakses ke arah sungai, menikmati pemandangan dan aktifitas sungai, sehingga dapat ikut menjaga fasilitas yang disediakan bagi kepentingan publik. Kenyataannya, aktifitas di tepian sungai Kapuas di wilayah Seng Hie, sangat terbatas pada pengguna langsung dari kawasan waterfront tersebut. Masyarakat diluar kawasan tidak dapat menikmati area waterfront dengan leluasa.

Berdasarkan hal tersebut, maka diperlukan penelitian mengenai keberadaaan akses publik dan open space di kawasan waterfront Seng Hie, apakah kondisi eksisting dikawasan ini sudah mengikuti kaidah waterfront city yang membuka akses dan open space untuk publik.

\section{Kajian Literatur}

Setiap kota harus memiliki keunikan, karakter, identitas dan spirit yang membedakannya dengan tempat lain. Hal ini menurut Garnham (1985) mencakup existing natural environment, cultural expression dan sensory experience (primary visual). Existing natural environment mencakup keadaan geografis yang membentuk kota seperti berada di perbukitan, di tepi pantai, di tepi sungai yang terbentuk oleh keadaan alam. Kehidupan masyarakat, cara bersosialisasi, budaya, adat istiadat setempat juga membedakan satu kota dengan kota yang lain. Tampilan kota yang dapat dinikmati melalui indera mata, berupa ciri khas arsitektur yang terbentuk oleh perbedaan existing natural environment dan kultur budaya setempat, juga menentukan image visual yang menjadi ciri khas sebuah kota.

Dengan demikian, kota yang memiliki sungai pada bagian tengah kota, seharusnya memperhatikan satuan fisik sungai sebagai bagian utama dalam perancangan Kota. Maka kota tersebut akan menghasilkan kerakter karena keberadaan sungai.

Waterfront secara harfiah dapat diartikan sebagai tepi air (water edges) atau badan air (water body). Kota (city) dan waterfront merupakan dua hal yang selalu digunakan secara bersamaan dan tidak dapat dipisahkan pengertiannya. Menurut Breen dan Rigby (1994), Hal ini dikarenakan suatu kota memiliki potensi air baik berupa sungai, danau, laut dan sebagainya dimana secara geografis membentuk suatu batas peralihan antar daerah perairan dengan daratan yang dikenal sebagai daerah tepi air.

Menurut buku Waterfront design and access dalam Jumaylinda (1997) mengemukakan ada 3 hal yang menjadi aspek perancangan waterfront pada kawasan waterfront city, yang akan membentuk karakter kota terutama karakter visual yaitu :

1. Akses publik dan open space ( ruang terbuka), yaitu berupa hal-hal yang memungkinkan turun tangan publik untuk menikmati air. Beberapa hal yang diperhatikan, yaitu:

- Visible connection to the water 
Memudahkan konektivitas ke air, yaitu dengan jalur sirkulasi.

- Connection to the promenade

Akses yang tidak terlihat langsung dari jalan utama, di desain menunjukkan kejelasan akses ke area air.

- Area identity

Karakter kawasan dan akses keunikan yang menggambarkan tujuan akses menuju air, yaitu dengan memperlihatkan aktivitas penyeberangan sungai menggunakan sampan.

- Required public access

Akses publik harus terletak di lantai dasar untuk memungkinkan berhubungan dengan air, yaitu fasilitas ruang terbuka dan tidak digunakan untuk aktifitas privat.

- Microclimate conditions

Desain ruang publik tanggap terhadap keadaan iklim setempat, yaitu dengan menyediakan tempat perlindungan dari angin dan sengatan matahari.

- Site improvements

Penyediakan fasilitas publik seperti toilet, lampu jalan, fasilitas rekreasi, memancing dan lain-lain.

- Commercial and ferry facilities

Aktivitas komersil melayani kegiatan rekreasi seperti restoran, menyediakan kenyamanan untuk menikmati suasana air. Fasilitas ferry atau sampan lebih dikembangkan untuk memfasilitasi pencapaian dari berbagai tempat.

- Design for securities

Menciptakan rasa nyaman dan aman untuk publik, terutama pada malam hari.

- Views

Desain memberikan kejelasan memandang ke segala arah.

- Material

Penggunaan material tahan terhadap efek yang diakibatkan kondisi waterfront seperti air dan lumut, serta mudah dibersihkan.

2. View

Berupa pemandangan yang dapat dinikmati dari berbagai lokasi di wilayah waterfront. Bagian yang dapat dinikmati berupa :

- Pemandangan tepi air pada persimpangan jalur sungai berupa pemandangan kapalkapal yang lalu lalang.

- Pemandangan aktifitas waterfront, seperti pelabuhan, penyeberangan sampan atau ferry, dan aktifitas memancing.

- Pemandangan sepanjang jalan tepi air, menyusuri jalan, melewati jembatan yang menghubungi wilayah waterfront.

- Pemandangan latar belakang (background) waterfront seperti pemukiman, kota, atau hutan.

- Pemandangan dari tempat tertinggi, misalnya dari gardu pandang untuk menikmati keseluruhan pemandangan waterfront. View dari arah sungai juga perlu dipertimbangkan sebagai pendukung aktifitas waterfront. Terutama view yang tercipta dari kualitas fasad bangunan pada kawasan tepi sungai, citra waterfront harus tetap terjaga.

3. Historic resource (sumber historis), yaitu nilai historis yang terkandung di kawasan, menceritakan budaya, alam kebiasaan, even setempat yang biasa dilakukan, yang menciptakan karakter arsitektur yang khas, berupa :

- Waterfront character

Ciri yang berhubungan dengan air sebagai pembentuk karakter. 
- Neighborhood character

Kesamaan bentuk dari bangunan-bangunan yang terletak ditepian air yang membentuk ciri tertentu

- Historic character

Nilai sejarah merupakan bagian dari pembentuk kota yang ditampilkan memalui bentu fasad dalam kawasan waterfront.

\section{Metodologi}

Lokasi penelitian yaitu berada di kawasan Seng Hie, tepatnya pada jalan Sultan Muhammad, yang merupakan kawasan komersil. Penelitian ini menggunakan pendekatan rasionalistik. Metode ini dipilih meningat kawasan ini merupakan area waterfront dan untuk meneliti kesesuaian kemanfaatan secara eksisting harus memperhatikan konteks teori waterfront yang sudah dilakukan sebelumnya. Lingkup penelitian ini meliputi:

1. Identifikasi terhadap akses publik dan open space berdasarkan kondisi fisik eksisting.

2. Evaluasi kesesuaian dengan kaidah waterfront.

Tahapan analisis data yang digunakan dalam Penelitian akses publik dan open space di kawasan waterfront Seng Hie, terbagi atas 2 (dua) tahap, yaitu mengidentifikasi akses publik dan open space di kawasan waterfront Seng Hie dan evaluasi kesesuaian dengan kaidah waterfront. Pemilihan sampling diambil berdasarkan variabel yang akan diamati. Tahap pertama adalah membagi objek amatan menjadi empat penggal, sesuai dengan keberadaan ruang berupa akses publik. Kemudian dilakukan identifikasi elemen akses publik dan open space, yang terdiri dari:

- Visible connection to the water

- Connection to the promenade

- Area identity

- Required public access

- Microclimate conditions

- Site improvements

- Commercial and ferry facilities

- Design for securities

- Views

- Material

Tahap kedua adalah melakukan evaluasi kesesuaian dengan kaidah waterfront. Kegiatan dalam tahapan ini adalah dengan mengevaluasi kondisi akses publik dan open space yang sudah diidentifikasi pada tahap pertama, apakah sudah sesuai dengan kaidah waterfront.

\section{Hasil dan Pembahasan}

Hasil analisis tahap pertama dijabarkan sebagai berikut:

\section{Visible connection to the water}

Pada keseluruhan penggal sudah terdapat promenade (jalur sirkulasi sejajar dengan sungai). Promenade berupa barau (talud) yang terbuat dari beton. Promenade bermanfaat untuk memastikan kemudahan akses ke sungai. Promenade pada yang tersedia pada keempat penggal juga dimanfaatkan untuk menambat sampan. Namun ada beberapa penambahan yang tidak permanen dan tampak tidak terencana, yaitu berupa tangga kayu dan digunakan untuk mandi dan cuci pakaian (hasil analisis dapat dilihat secara lengkap pada lampiran dengan judul Analisis 1, Elemen Connection to the promenade dan Visible connection to the water). 


\section{Connection to the promenade}

Pada keempat penggal sudah terdapat akses menuju sungai (hasil analisis dapat dilihat secara lengkap pada lampiran dengan judul Analisis 1, Elemen Connection to the promenade dan Visible connection to the water). Dan akses tersebut mengarah pada promenade yang berada berhadapan langsung dengan sungai. Bentuk dan lebar akses pada setiap penggal bervariasi, dan pada pembagian tiap penggal terdapat muara-muara sungai menuju kawasan di sekitar jalan Sultan Muhammad. Tetapi secara umum akses yang tersedia tidak dapat memberikan kejelasan, bahwa ada sungai di arah tujuan dari akses tersebut.

Akses yang tersedia juga tidak memberikan kesan mengundang untuk menuju arah sungai. Tidak terdapat penunjuk arah ataupun keberadaan sungai tidak tampak jelas dari arah jalan. Bahkan pada beberapa akses tertutup oleh PKL dan barang yang menutup pemandangan menuju akses ke sungai.

\section{Area identity}

Aktifitas yang terjadi di kawasan yang berhubungan langsung dengan sungai, memberi karakter waterfront secara jelas, yaitu dengan adanya aktifitas persampanan dan perkapalan. Tetapi pada bagian yang berhubungan langsung dengan jalan sultan Muhammad, aktifitas perdagangan sangat mendominasi, dan menyamarkan bahwa ada area sungai yang mungkin saja menarik untuk aktifitas publik. Kegiatan bongkar muat barang, parkir kendaraan besar seperti truk dan aktifitas yang sangat sibuk di siang hari menyebabkan aktifitas di sungai tidak terlihat dengan jelas (hasil analisis dapat dilihat secara lengkap pada lampiran dengan judul Analisis 1, Elemen Area identity dan Required public access)

\section{Required public access}

Pada bagian dasar dari kawasan yang berhubungan langsung dengan sungai, dapat diakses dan digunakan oleh publik. Tetapi penggunaannya belum dapat dimanfaatkan secara maksimal. Terlihat dari sedikitnya aktifitas publik yang dapat ditemui di kawasan ini. Hal ini kemungkinan terjadi karena ruang yang tercipta antara bangunan dan promenade adalah genangan air yang dalam, atau masih merupakan badan sungai yang merupakan hasil reklamasi sungai, sehingga air sungai masih menjadi dasar dari ruang terbuka di kawasan ini. Keberadaan air ini membuat ruang terbuka tidak dapat dimanfaatkan secara maksimal, bahkan menghasilkan ketakutan jatuh ke bagian sungai tersebut (hasil analisis dapat dilihat secara lengkap pada lampiran dengan judul Analisis 1, Elemen Area identity dan Required public access)

\section{Microclimate conditions}

Pada kawasan ini sudah terdapat tempat berteduh yang diletakkan pada beberapa titik dan keberadaannya berpencar, namun kondisinya belum maksimal karena ada yang belum permanen, tidak rapi dan bahkan ada yang terkesan liar, karena dibuat masyarakat sebagai kios PKL (hasil analisis dapat dilihat secara lengkap pada lampiran dengan judul Analisis 1, Elemen Microclimate conditions dan Site improvements)

\section{Site improvements}

Fasilitas di kawasan ini bisa dikatakan kurang memadai, karena yang tersedia hanya lampu jalan yang tidak sepenuhnya dapat berfungsi denga baik karena sebagian yang tersedia hanya tiang lampu dan belum dilengkapi dengan bola lampu. Di kawasan ini juga belum ada toilet sebagai pelayanan aktifitas kawasan waterfront. Kawasan ini belum ada tempat memancing khusus, masyarakat memancing pada area-area yang mereka anggap nyaman dan menghasilkan ikan untuk dipancing. Fasilitas untuk fasilitas memancing belum tersedia, yaitu 
kebutuhan akan tiang-tiang untuk menancapkan alat pancing (hasil analisis dapat dilihat secara lengkap pada lampiran dengan judul Analisis 1, Elemen Microclimate conditions dan Site improvements).

\section{Commercial and ferry facilities}

Aktifitas penyeberangan yang tersedia pada kawasan ini berupa sampan saja, tidak ada ferry yang dibuat khusus untuk menikmati kawasan waterfront ini. Namun diluar kawasan ini, disediakan kapal wisata yang memiliki route pergerakan dari area alun-alun kota Pontianak menuju bagian bawah jembatan kapuas 1, dan memutar lagi menuju arah Tugu Khatulistiwa. Namun sampan-sampan yang biasanya tertambat di promenade juga melayani aktifitas penyeberangan ke area sungai yang lain. Sampan-sampan yang tertambat di promenade tidak dapat ditampung semua di dermaga apung, sehingga memenuhi promenade di sepanjang kawasan ini (hasil analisis dapat dilihat secara lengkap pada lampiran dengan judul Analisis 1, Elemen Commercial and ferry facilities dan Design for securities).

\section{Design for securities}

Pada kawasn ini masih kurang memberikan rasa aman. Ini terbukti dari banyaknya tiang lampu yang tidak memiliki bola lampu, dan ini memastikan bahwa kawasan ini gelap pada saat malam. Promenade di kawasan ini juga belum semuanya memiliki pagar pengaman, untuk menjaga keselamatan pejalan kaki di jalur ini (hasil analisis dapat dilihat secara lengkap pada lampiran dengan judul Analisis 1, Elemen Commercial and ferry facilities dan Design for securities).

\section{Views}

Pada kawasan ini, apabila dilihat dari arah promenade, pengunjung dapat melihat secara luas kesegala arah, meliputi seluruh wilayah perairan dan kawasan diseberang sungai yaitu area Beting dan Siantan. Keleluasan ini memberi pemandangan yang menarik terutama pada aktifitas sungai berupa penyeberangan sungai dan bongkar muat barang di area perkapalan (hasil analisis dapat dilihat secara lengkap pada lampiran dengan judulAnalisis 1, Elemen Views dan Material).

\section{Material}

Material yang diterapkan pada promenade berupa beton, dan sudah mempertimbangkan efek yang ditimbulkan dari hempasan gelombang, yaitu dengan menggunakan beton. Tetapi pada sebagian dermaga masih ada yang terbuat dari kayu yang rentan terhadap hempasan air sungai (hasil analisis dapat dilihat secara lengkap pada lampiran dengan judul Analisis 1, Elemen Views dan Material).

Analisis tahap kedua dilakukan dengan melakukan menganalisis hasil identifikasi akses publik dan open space, dengan kaidah waterfront. Berdasarkan kondisi eksisting, kawasan ini merupakan kawasan waterfront dengan typologi kawasan komersial, dimana ketentuan yang diharuskan terjadi di kawasan ini yaitu:

1) Harus mampu menarik perhatian pengunjung

2) Memiliki kegiatan yang menarik dan memberikan kenyamanan dan keamanan bagi pengunjung

3) Memiliki keunikan budaya setempat

4) Memiliki sarana untuk bersosialisasi dan juga aktifitas komersial

5) Memperhatikan bentuk fisik kawasan sebagai faktor utama untuk menarik pengunjung 
Berdasarkan hasil identifikasi yang telah dilakukan pada tahap pertama, kawasan bagian belakang dari kawasan komersil jalan Sultan Muhammad, belum mampu menarik perhatian pengunjung. Akses yang berhadapan dengan jalan kebanyakan ditutupi dengan adanya PKL (lihat gambar 4.1). Keberadaan PKL yang banyak dan panjang serta berkesan kumuh membuat orang tidak tertarik untuk berkunjung (lihat gambar 4.2). Akses yang tersedia juga beragam lebar dan beragam kondisi fisiknya. Ada yang telah dibangun permanen sehingga berkesan kokoh, sedangkan ada juga yang masih menggunakan kayu serta hampir roboh karena konstruksi yang rusak dan sudah tua (lihat gambar 4.3).

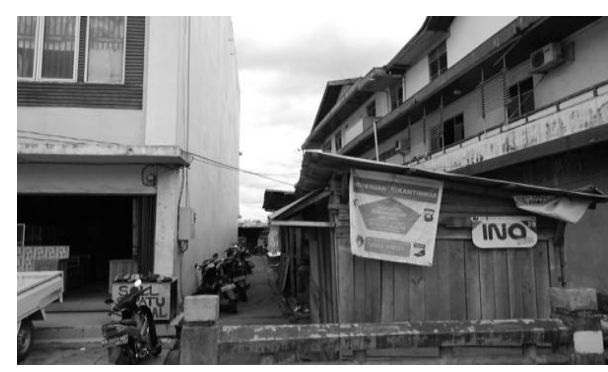

Gambar 1. Akses ditutupi PKL

Sumber: Survey, 2015
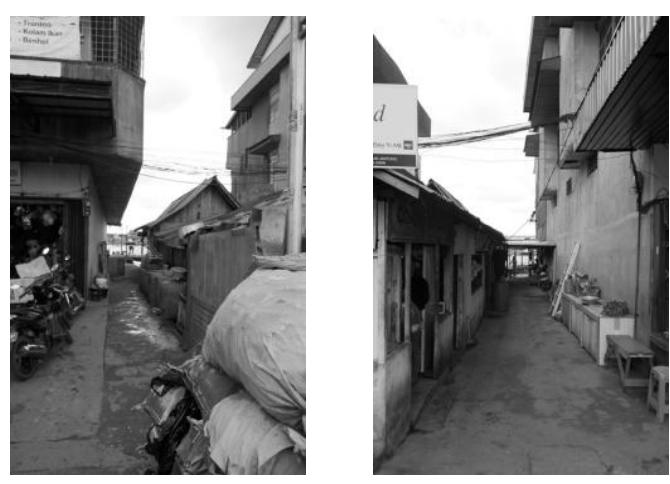

Gambar 2. Akses ditutupi PKL dan berkesan kumuh Sumber: Survey, 2015

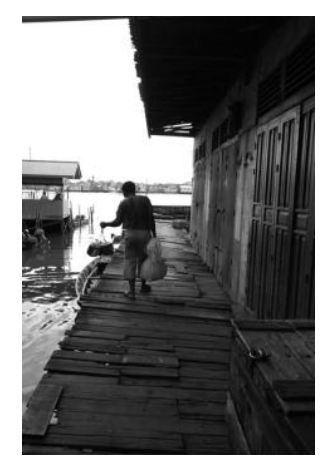

Gambar 3. Konstruksi hampir roboh dan rusak Sumber: Survey, 2015

Kawasan ini telah dilengkapi dengan adanya promenade sebagai jalur sirkulasi di bagian yang berhubungan langsung dengan air, dan promenade ini terbuat dari material beton yang berfungsi sebagai barau (talud) dan menjadi pembatas antara area darat dan area air. Namun lebar promenade belum bisa melayani aktifitas publik dan memberi kenyamanan pada pengunjung. Terbukti dengan diberikannya tambahan papan-papan untuk memperlebar 
ruang gerak pada promenade, dan ditambahkan pula tangga-tangga kayu serta dermaga apung dari kayu untuk memperluas ruang gerak pengunjung (lihat gambar 4.4).
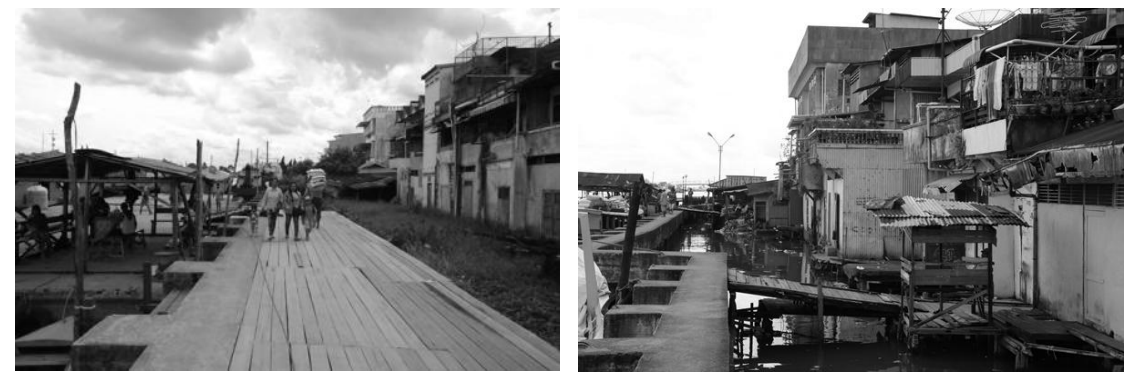

Gambar 4. Ruang gerak di atas promenade Sumber: Survey, 2015

Aktifitas penyeberangan sungai menggunakan sampan, merupakan keunikan khas yang dimiliki kawasan ini (lihat gambar 4.5). Aktifitas ini juga dapat dinikmati disepanjang promenade. Selain itu, aktifitas mancing yang menyebar juga menjadi ketertarikan sendiri, walaupun belum tersedia tempat khusus dan fasilitas pendukungnya.

Pada bagian promenade yang dimanfaatkan untuk aktifitas memancing dan menambatkan sampan, belum terdapat sarana untuk bersosialisasi dengan maksimal. Yang di sediakan hanya berupa tempat berteduh sementara dari panas dan angin sambil menunggu sampan yang diinginkan. Sedangkan sarana untuk menikmati keindahan sungai belum tersedia dengan baik. Promenade yang tersedia juga belum memberikan rasa nyaman dan aman, karena belum tersedia pagar pembatas agar pengunjung tidak jatuh ke sungai.

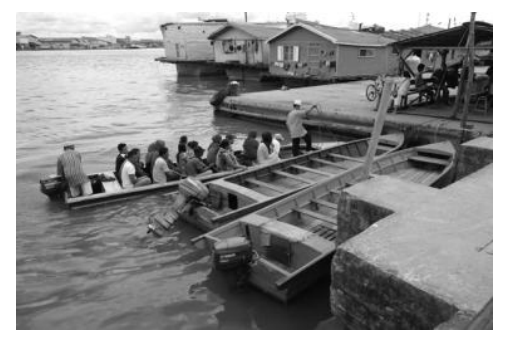

Gambar 5. Aktifitas penyeberangan menggunakan sampan Sumber: Survey, 2015

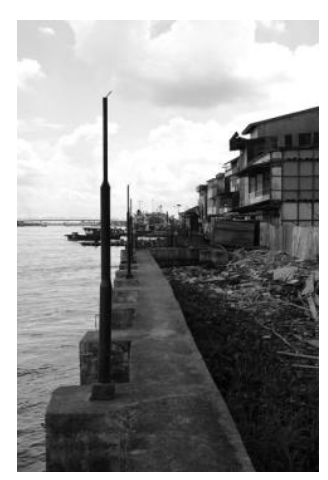

Gambar 6. Promenade belum memberikan rasa aman dan nyaman Sumber: Survey, 2015 


\section{Kesimpulan}

Kawasan waterfront Seng Hie, memiliki keunikan yang memberi karakter yang menjadi citra Kota Pontianak. Kawasan ini sangat berpotensi untuk dikembangkan. Kawasan ini sudah memiliki daya tarik dilihat dari fungsi yang melekat yaitu perdagangan. Ini membuat kawasan ini sebenarnya sangat mudah menjadi magnet yang mengundang lebih banyak orang berkunjung.

Menurut potensi lokasi yaitu berada di tepi sungai Kapuas, kawasan yang berhadapan langsung dengan sungai, seharusnya dapat dinikmati oleh masyarakat umum Pontianak. Namun kenyataannya, banyak kondisi yang menghalangi akses menuju sungai sehingga orang yang melintas tidak mengetahui dan tertarik untuk berkunjung ke tepian sungai. Salah satunya adalah dengan adanya PKL yang menutupi akses menuju ke arah promenade serta menutupi secara visual. PKL ini juga menyebabkan kekumuhan, akibat dari aktifitas yang menghasilkan sampah. Begitu pula dengan aktifitas sementara, seperti bongkar muat barang tepat di akses masuk menuju promenade, membuat akses menuju sungai menjadi tertutup.

Promenade yang tersedia juga sudah terbuat dari material beton yang berfungsi sebagai pembatas antara area bagian sungai dan bagian darat. Namun, promenade yang tersedia belum bisa dimanfaatkan untuk aktifitas publik, karena dimensi lebar promenade yang kecil. Hal lain yang membuat aktifitas terganggu yaitu karena pada bagian darat belum ditutupi dengan penutup tanah atau lantai, sehingga belum memberi rasa nyaman dan aman bagi pengunjung.

Aktiftas eksisting yang ramai, yaitu dengan adanya penyeberangan menggunakan sampan dan kapal, membuat kawasan ini memiliki karakter yang sangat menarik. Aktifitas ini mengundang untuk ditonton dan menjadi area bersantai, namun fasilitas bersantai belum disediakan secara maksimal. Masyarakat yang berada di kawasan ini memanfaatkan potensi yang ada dengan menyediakan tempat berlindung berupa PKL. Sedangkan tempat berteduh yang telah disediakan di tempat ini, belum tersedia merata. Di kawasan ini juga belum tersedia toilet sebagai fasilitas utama yang mendukung aktifitas publik.

Aktifitas memancing juga banyak ditemui di kawasan ini. Aktifitas ini juga menjadi magnet yang mengundang masyarakat untuk datang ke kawasan ini, walaupun belum tersedia tempat dan fasilitas yang mendukung aktifitas ini. Aktifitas penyeberangan di kawasan ini juga tampak ramai, dan sampan-sampan yang ada belum bisa di tampung semua sehingga sampan tertambat di sekitar promenade. Penumpang sampan yang menggunakan sarana ini menjadi terhambat, kesulitan menghantarkan barang ke sampan, karena tidak melalui dermaga, tatapi melewati promenade.

Kawasan ini juga sudah memberi lampu sebagai sarana penerangan pada malam hari, tetapi belum semua tiang lampu memiliki bola lampu sehingga kawasan ini pasti menjadi gelap. Tidak adanya pagar pada setiap penggal juga membuat kawasan ini belum bisa memberikan ranya aman jika berjalan-jalan di atas promenade.

Posisi kawasan waterfront Seng Hie ini sangat strategis, berada di persimpangan sungai tepat di tengah kota Pontianak. Sehingga memberikan pemandangan yang sangat menarik ke segala arah. Apalagi dari kawasan ini dapat melihat kawasan heritage di seberang sungai, akan menjadi potensi yang sangat menguntungkan.

Paparan diatas menjelaskan bahwa banyak hal yang harus dilakukan pada akses publik dan open space di kawasan waterfront Seng Hie, sehingga kawasan ini memberikan kesan mengundang masyarakat untuk datang. Walaupun sudah dilengkapi dengan fasilitas pendukung berupa promenade, ternyata bentuk fisik kawasan sebagai faktor utama untuk menarik pengunjung, sehingga menarik perhatian pengunjung. 


\section{Daftar Pustaka}

Breen, Ann dan Dick Rigby. (1994). Waterfront, Cities Reclaim Their Edge. Mc.Graw Hill. New York

Breen, Ann dan Dick Rigby. (1996). The New Waterfront: A Worldwide Urban Success Story. Mc.Graw Hill. New York

Department of City Planning, Waterfront Urban Design Technical Advisory Committee. (1997). The Port of San Francisco Waterfront Design \& Access: An Element of the Waterfront Land Use Plan, Port of San Francisco. San Francisco.

Garnham, Harry Launce. (1985) Maintaining the Spirit of Place: a Process for the preservation of Town Character. PDA Publisher Corp. Madison

Garnham. H. L. (1976). Maintaining the Spirit of Place: A Guidebook for Citizen/professional Participation in the Preservation and Enhancement of Small Texas Towns. A \& M University Printing. Texas.

Jumaylinda. (2007). Kualitas Visual Fasad Bangunan Komersil Seng Hie. Thesis. UGM. Yogyakarta

Maryono, Agus; Parikesit, Danang. (2003). Transportasi Sungai Mulai Ditinggalkan. Kompas, 01 Mei 2003

Wrenn, Douglas M, dkk. (1983). Urban Waterfront Development. Urban Land Institute. Michigan 


\section{Lampiran}

Analisis 1, elemen "Connection to the promenade" dan "Visible connection to the water

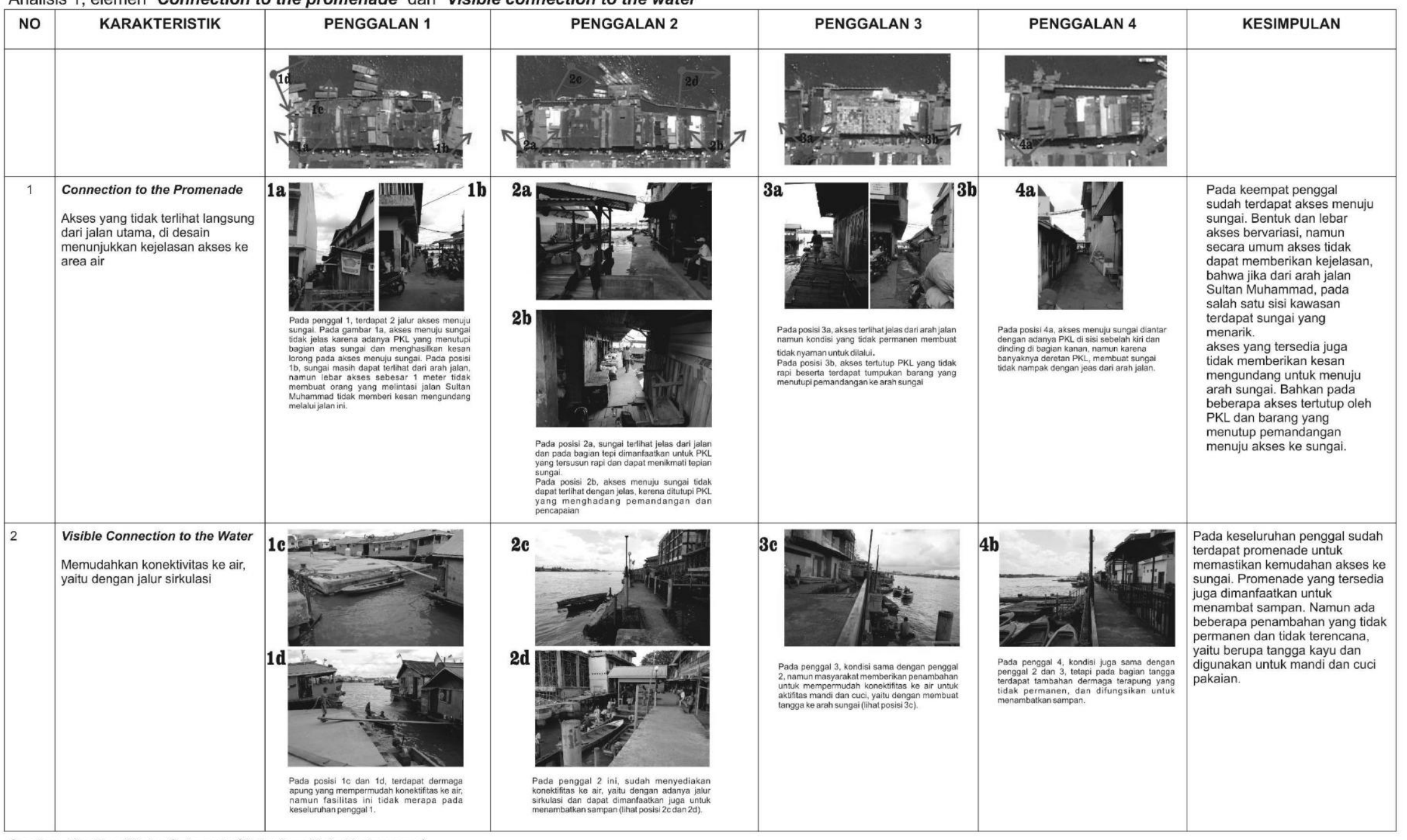

Sumber : Tim Peneliti dan Suharnoto (Mahasiswa Univ. Tanjungpura) 
Analisis 1, elemen "Microclimates conditions" dan "Site improvements"

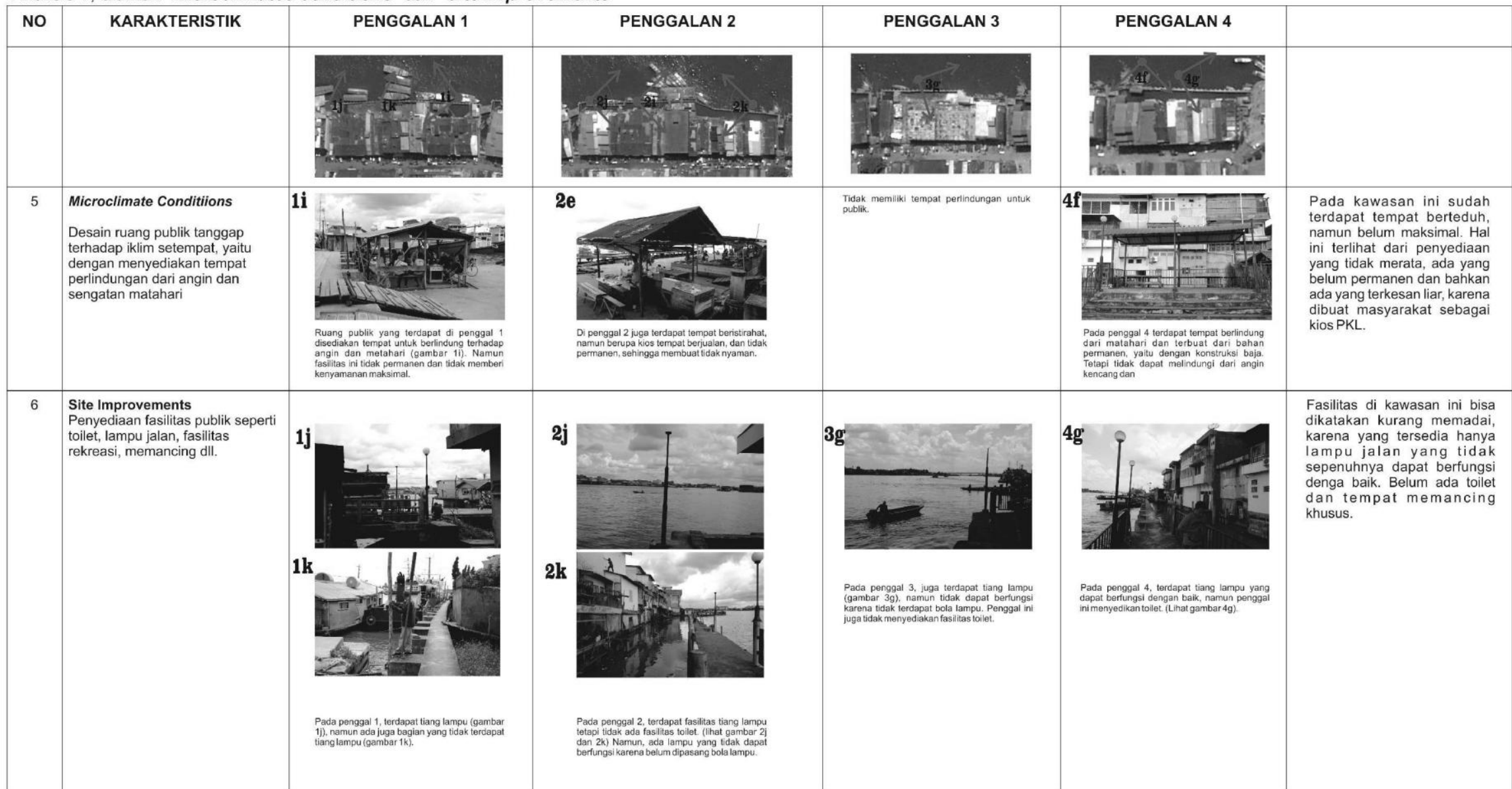

Sumber : Tim Peneliti dan Suharnoto (Mahasiswa Univ. Tanjungpura) 
Analisis 1, elemen "Commercial and ferry facilities" dan "Design for sucurities"

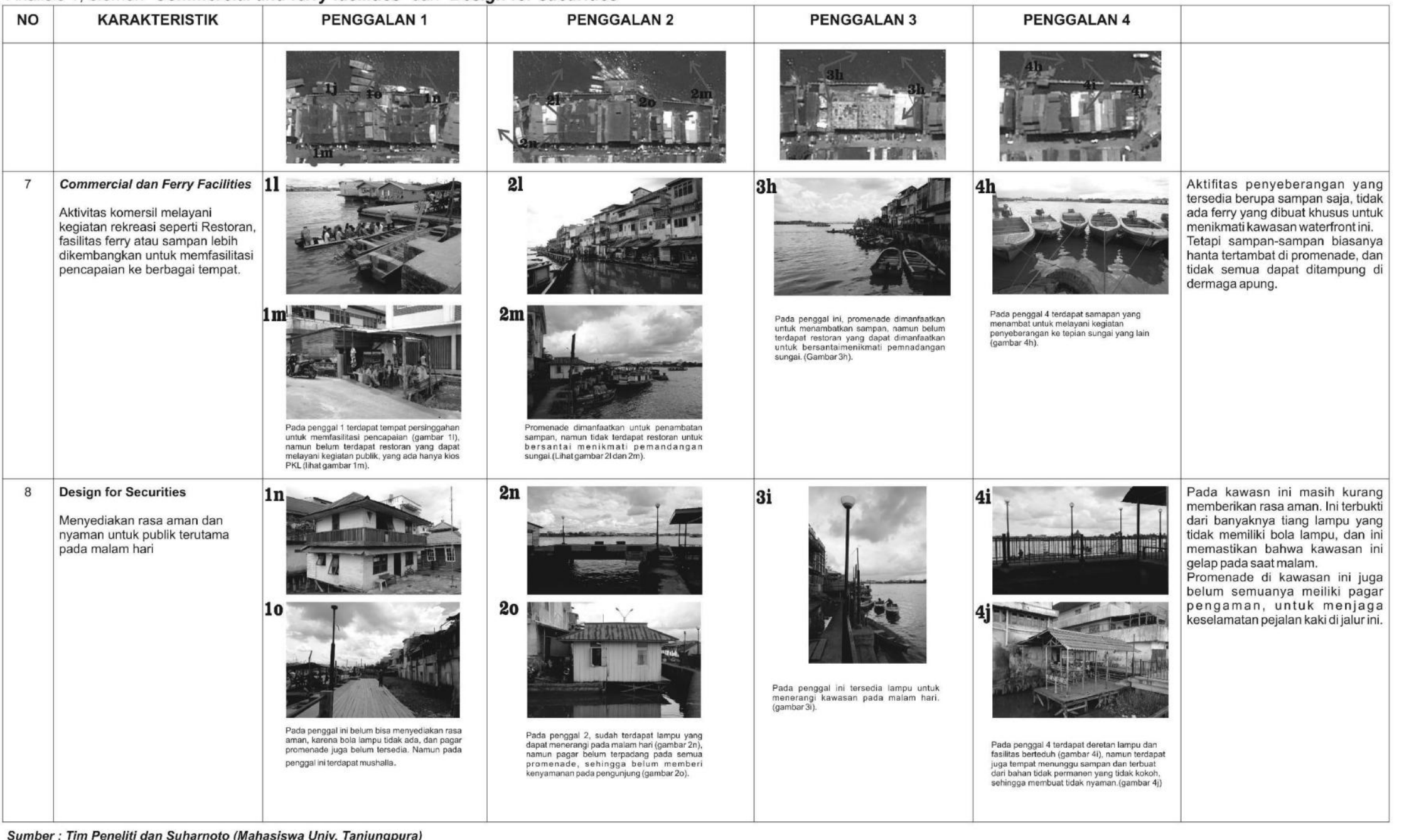

